\title{
Carbon dioxide and methane emissions from interfluvial wetlands in the upper Negro River basin, Brazil
}

\author{
Lauren Belger • Bruce R. Forsberg • \\ John M. Melack
}

Received: 23 February 2010/Accepted: 9 October 2010/Published online: 1 November 2010

(C) The Author(s) 2010. This article is published with open access at Springerlink.com

\begin{abstract}
Extensive interfluvial wetlands occur in the upper Negro River basin (Brazil) and contain a mosaic of vegetation dominated by emergent grasses and sedges with patches of shrubs and palms. To characterize the release of carbon dioxide and methane from these habitats, diffusive and ebullitive emissions and transport through plant aerenchyma were measured monthly during 2005 in permanently and seasonally flooded areas. $\mathrm{CO}_{2}$ emissions averaged $2193 \mathrm{mg} \mathrm{C} \mathrm{m}^{-2}$ day $^{-1}$. Methane was consumed in unflooded environments and emitted in flooded environments with average values of -4.8 and $60 \mathrm{mg} \mathrm{C} \mathrm{m}^{-2}$ day $^{-1}$, respectively. Bubbles were emitted primarily during falling water periods when hydrostatic pressure at the sediment-water interface declined. $\mathrm{CO}_{2}$ and $\mathrm{CH}_{4}$ emissions increased when dissolved $\mathrm{O}_{2}$ decreased and vegetation was more abundant. Total area and seasonally varying flooded areas for two wetlands, located north and south of the Negro River,
\end{abstract}

L. Belger $(\varangle)$

Fundação do Meio Ambiente de Itajaí, Rua XV de

Novembro, 215, Itajaí, SC 88301-420, Brazil

e-mail: laurenbelger@hotmail.com

L. Belger · B. R. Forsberg

Instituto Nacional de Pesquisas da Amazônia, INPA-

CPEC, C.P. 478, Manaus, AM 69011-970, Brazil

J. M. Melack

Bren School of Environmental Science and Management, University of California, Santa Barbara,

CA 93106-5131, USA were determined through analysis of synthetic aperture radar and optical remotely sensed data. The combined areas of these two wetlands $\left(3000 \mathrm{~km}^{2}\right)$ emitted $1147 \mathrm{Gg} \mathrm{C}_{\text {year }}{ }^{-1}$ as $\mathrm{CO}_{2}$ and $31 \mathrm{Gg} \mathrm{C}$ year $^{-1}$ as $\mathrm{CH}_{4}$. If these rates are extrapolated to the area occupied by hydromorphic soils in the upper Negro basin, $63 \mathrm{Tg} \mathrm{C}_{\text {year }}{ }^{-1}$ of $\mathrm{CO}_{2}$ and $1.7 \mathrm{Tg} \mathrm{C}_{\text {year }}{ }^{-1}$ as $\mathrm{CH}_{4}$ are estimated as the regional evasion to the atmosphere.

Keywords Amazon - Carbon dioxide · Methane · Upper Negro basin · Wetland

\section{Introduction}

Natural wetlands in central Amazon floodplains emit to the atmosphere considerable amounts of carbon dioxide and methane (Richey et al. 2002; Melack et al. 2004). However, the degree to which emissions from these floodplains are representative of the variety of wetlands throughout the Amazon basin (Melack and Hess 2010) is unknown. One of the largest wetland systems, distinctive ecologically and hydrologically from the central floodplains, is in the western lowlands of the Negro River basin. These ecosystems, known regionally as chavascal, campina or capinarana, are characterized by shallow permanently or seasonally flooded areas covered with perennial herbaceous macrophytes rooted in the soil (predominantly Cyperaceae and Poaceae), intermingled with small trees, shrubs and palms (predominantly 
Mauritia flexuosa) (Junk 1993). They tend to be oxygenated environments, which favor aerobic metabolism. Their flooding patterns, morphology and vegetation are similar to those described for the wet savannas of northern Roraima (Hamilton et al. 2002; Ferreira et al. 2007) but are distinct from those encountered on the deeply inundated, central Amazon floodplain, where most measurements of gas evasion have been made. Wetlands along the central Amazon floodplain are dominated by dense stands of forest and extensive areas with floating herbaceous vegetations, characteristics which promote anoxic conditions and favor methanogenesis. The emissions from the Negro River's interfluvial wetlands are thus expected to differ considerably from those previous reported for the central floodplain.

Air-water gas exchange is affected by numerous factors including vegetative cover, dissolved gas concentrations, water depth, variations in hydrostatic pressure, wind, and temperature (MacIntyre et al. 1995; Whalen 2005). Under aerobic conditions $\mathrm{CO}_{2}$ is produced, and under anoxic conditions $\mathrm{CO}_{2}$ and $\mathrm{CH}_{4}$ are produced. When sediments are flooded and became anoxic, methane is produced by methanogenesis; when sediments are aerobic, methane is consumed by microbial-mediated oxidation (Matson and Harriss 1995). Methane evasion occurs via diffusion, bubbling (ebullition) and transport through plants, while diffusion is the primary route of $\mathrm{CO}_{2}$ emission. Bubbling reduces the amount of oxidation of methane and can represent most of the $\mathrm{CH}_{4}$ emissions from Amazon wetlands (Devol et al. 1988; Engle and Melack 2000). Plants can enhance $\mathrm{CH}_{4}$ emission by providing organic substrates and by functioning as conduits, allowing $\mathrm{CH}_{4}$ to bypass the aerobic zone of potential oxidation (Dacey and Klug 1979). Conversely, plants can attenuate $\mathrm{CH}_{4}$ emission by facilitating $\mathrm{CH}_{4}$ oxidation through transport and release of $\mathrm{O}_{2}$ from roots located in anoxic soils (Whalen 2005). $\mathrm{CO}_{2}$ and $\mathrm{CH}_{4}$ can accumulate when the water column is stratified (Crill et al. 1988), but when water level is falling, hydrostatic pressure decreases, and methane can be released by ebullition (Rosenqvist et al. 2002).

The objective of our work was to expand understanding of emission of $\mathrm{CH}_{4}$ and $\mathrm{CO}_{2}$ from tropical ecosystems by conducting measurements in the extensive interfluvial wetlands of the upper Negro basin. Our monthly measurements of $\mathrm{CO}_{2}$ and $\mathrm{CH}_{4}$ emitted by ebullition, diffusion and transport through plants were used to investigate the influence of habitat types, water depth, hydrostatic pressure variation, dissolved oxygen and water temperature on emissions. We used a time series of synthetic aperture radar (SAR) data complemented by Landsat data to develop a time series of inundated area for two interfluvial wetlands to extend our field measurements spatially.

\section{Methods}

Study area

The study was done in three interfluvial wetlands of the Negro River basin, located in the northwestern Brazilian Amazon (Fig. 1). The Cuini wetland is located on the southern side of the Negro River between the Cuini and Ararirá rivers (Fig. 2). The Itu wetland is located on the northern side of the Negro River in the headwaters of the Itu River. The Aracá wetland is located on the western side of the Aracá River. Flooding varied seasonally, and extensive parts of the Cuini wetland were permanently flooded while the Itu and Aracá wetlands dried several months per year. In the high-water season, the Cuini site was no more than $0.6 \mathrm{~m}$ deep (with the exception of streams channels), while Itu site was up to $1.3 \mathrm{~m}$ deep and Aracá site was up to $0.8 \mathrm{~m}$ deep. The soils and sediments at the Itu and Aracá sites were composed predominantly of coarse sand while the sediments at the Cuini site consisted of fine grained organic mud.

\section{Sampling design}

At the Cuini and Itu sites measurements were made monthly from February 2005 to January 2006 at stations where boardwalks were constructed to avoid release of gases caused by the person making the collections. At the Itu site a total of eight stations representing palms, shrubs, grasses or open water were selected. At the Cuini site five stations were sampled because palm dominated locations did not occur and only one open water locale was sampled. Supplementary measurements were made occasionally at other points in Itu and Cuini wetlands. The Aracá site was especially difficult to access, and it was visited only three times with measurements made in open water, grass, shrub and flooded forest habitats. Sampling points were located with a global positioning unit. 
Fig. 1 Location of three study sites. Black represents water courses, white represents upland forest and gray represents seasonally flooded areas

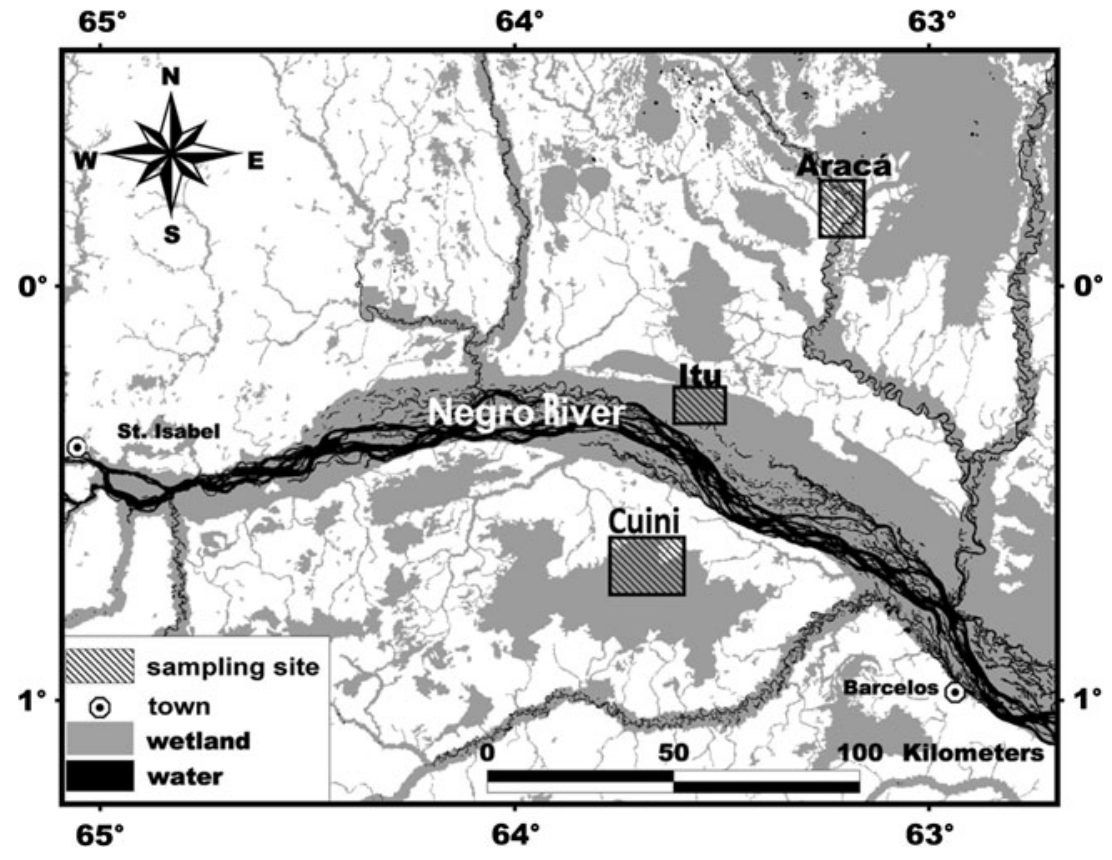

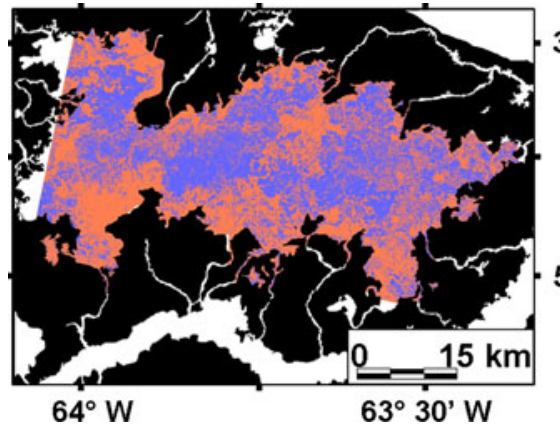

Fig. 2 Inundation of Cuini wetland at low water (left) and high water (right). Black indicates uplands, and white denotes flooded area outside of Cuini wetland. Blue (darker central

Physicochemical conditions

Dissolved oxygen was measured with a polarographic electrode every $10 \mathrm{~cm}$ at each site from April to August 2005 at the Itu and Cuini stations; superficial temperature was measured with a thermistor (Yellowsprings Model 55). Water depths were measured manually at each location on each visit. Depth and temperature were also measured at the deepest locale found in each of the three wetlands by pressure transducers and thermistors linked to data loggers (Levelogger Solinst model 3001); data were record daily every midnight. Rainfall was recorded at each site with tipping bucket rain gauges. Staff gauges graduated in centimeters were
35 's

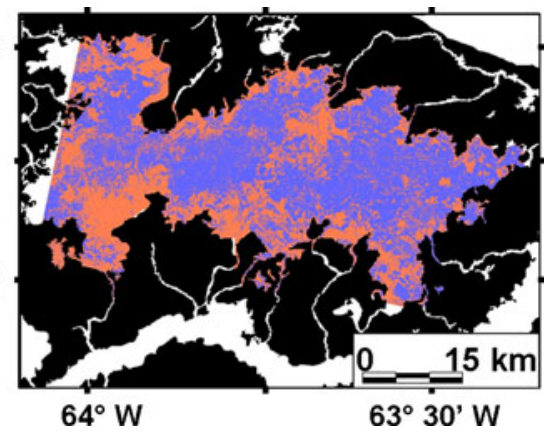

regions) indicates flooded habitats and orange (brighter) indicates unflooded habitats or regions where vegetation did not permit detection of inundation. (Color figure online)

installed on the banks of the Negro River and Aracá River and read daily by local observers (Table 1 ).

Determination of gas concentrations in air and water

Duplicate samples of atmospheric air were taken monthly $0.5 \mathrm{~m}$ above the surface at each station. Air was collected with $60 \mathrm{ml}$ syringes and transferred to $25 \mathrm{ml}$ glass vials, previously filled with distilled water and closed with dense rubber stoppers and aluminum crimp seals. To transfer the gas, two needles were inserted through the stoppers, one to introduce the gas and the other to allow the water to exit. 
Table 1 Location of rain gauges and recording water level gauges at Cuini, Itu and Aracá sites and of the staff gauges on Negro and Aracá rivers

\begin{tabular}{llll}
\hline Instrument & Site & \multicolumn{2}{l}{ Location } \\
\cline { 2 - 4 } & & Latitude & Longitude \\
\hline Rain gauge & Cuini site & $-0.6631^{\circ}$ & $-63.5556^{\circ}$ \\
& Itu site & $-0.2863^{\circ}$ & $-63.5590^{\circ}$ \\
& Aracá site & $+0.2227^{\circ}$ & $-63.2238^{\circ}$ \\
Recording stage gauge & Cuini site & $-0.6648^{\circ}$ & $-63.5622^{\circ}$ \\
& Itu site & $-0.2903^{\circ}$ & $-63.5637^{\circ}$ \\
Staff gauge & Aracá site & $+0.2227^{\circ}$ & $-63.2238^{\circ}$ \\
& Negro River & $-0.5743^{\circ}$ & $-63.4570^{\circ}$ \\
& Aracá River & $-0.0979^{\circ}$ & $-63.3481^{\circ}$ \\
\hline
\end{tabular}

Collections of gases dissolved in water were made in duplicate at the stations in the Cuini and Itu wetlands as well as at supplementary locations occasionally for a total of 84 and 118 points, respectively, sampled from July 2005 to January 2006, and at the Aracá site at a total of 62 points sampled in July, August, and November 2005. The concentrations of $\mathrm{CO}_{2}$ and $\mathrm{CH}_{4}$ in the water were determined by the "headspace" method (Hope et al. 1995): $30 \mathrm{ml}$ of water was collected in a $60 \mathrm{ml}$ syringe, $30 \mathrm{ml}$ of atmospheric air introduced, and the syringe shaken vigorously about 100 times. The mixture of gases was then transferred to a $25 \mathrm{ml}$ glass vial, as described above, and held for analysis.

The concentrations of $\mathrm{CO}_{2}$ and $\mathrm{CH}_{4}$ were determined with a gas chromatograph (Shimadzu GC14A) equipped with a flame ionization detector for the analysis of $\mathrm{CH}_{4}$ and thermal conductivity detector for $\mathrm{CO}_{2}$, as described by Hamilton et al. (1995). Two standards were used of each gas: 335 and 995 ppm for $\mathrm{CO}_{2}$ and 10 and $50 \mathrm{ppm}$ for $\mathrm{CH}_{4}$. Detection limits were $100 \mathrm{ppm}$ for $\mathrm{CO}_{2}$ and $0.1 \mathrm{ppm}$ for $\mathrm{CH}_{4}$. The concentrations of the gases in the water were calculated using partition coefficients $\left(\mathrm{B}_{\mathrm{aw}}\right)$ as follows: Under standard conditions of pressure and temperature (1 atm and $25^{\circ} \mathrm{C}$ ), $\mathrm{B}_{\mathrm{aw}} \mathrm{CO}_{2}=1.5: 1$ (Broecker and Peng 1982) and $\mathrm{B}_{\mathrm{aw}} \mathrm{CH}_{4}=27: 1$ (Hansch and Leo 1979).

Determination of gas emissions

Emissions of $\mathrm{CO}_{2}$ and $\mathrm{CH}_{4}$ were measured in the Cuini and Itu wetlands with floating chambers and inverted funnels when habitats were flooded and with terrestrial chambers when the environment was unflooded based on methodology described in Rosenqvist et al. (2002). Chambers were vented to adjust for pressure changes during deployment and contained a fan to circulate air inside. Floating chambers were $25 \mathrm{~cm}$ in diameter and had an internal headspace volume of $10 \mathrm{l}$. Terrestrial chambers were $31 \mathrm{~cm}$ in diameter. Their internal volume was 151 , but it was reduced after deployment, and headspace volume for each chamber was revised based on five height measurements. Emission measurements made by floating and terrestrial chambers lasted $15 \mathrm{~min}$, and samples of gas were taken at $5 \mathrm{~min}$ intervals with $60 \mathrm{ml}$ polyethylene syringes. Funnels were $10 \mathrm{~cm}$ in diameter and were placed just under the water surface. They were deployed for $24 \mathrm{~h}$ and accumulated gas was collected with $10 \mathrm{ml}$ polyethylene syringes and the volume was noted. Samples were transferred to $25 \mathrm{ml}$ serum bottles capped with high density black butyl rubber stoppers until analysis.

Monthly measurements were made at each station in duplicate. A total of 156 sample pairs were taken, nine when locales were unflooded and 33 with insufficient depth for use of the inverted funnels. When possible (38 samples), the pair of floating chambers was positioned side by side, one over open water and the other over an emergent macrophyte to measure $\mathrm{CH}_{4}$ transport through aerenchyma.

Funnels measured ebullition and floating chambers determined primarily diffusive emissions. Following Smith et al. (2000), if the linear regression of gas flux versus time had $p<0.05$, the flux was considered diffusive. We used an additional criterion of $\mathrm{R}^{2}>0.8$ to consider emission measured in chamber only diffusive. Chamber results that did not meet these criteria were analyzed one by one. An abrupt increase in gas concentration was considered ebullition. The amount of gas emitted by ebullition was calculated as the distance between the extensions of two parallel lines formed by diffusive emission rates before and after the bubbling.

Diffusive emissions were also calculated from the concentrations of $\mathrm{CO}_{2}$ and $\mathrm{CH}_{4}$ in the water using Fick's law of diffusion (Eq. 1):

$\mathrm{F}=\mathrm{K}_{\mathrm{L}}\left(\mathrm{C}_{\mathrm{w}}\right.$ minus $\left.; \mathrm{C}_{\mathrm{eq}}\right)$

$F \quad$ flux, $\mathrm{mg} \mathrm{m}^{-2} \mathrm{day}^{-1}$

$K_{L}$ piston velocity, $\mathrm{m} \mathrm{day}^{-1}$ 
$C_{w} \quad$ gas concentration in water, $\mathrm{mg} \mathrm{m}^{-3}$

$C_{e q}$ equilibrium gas concentration, $\mathrm{mg} \mathrm{m}^{-3}$

$K_{L}$ represents all the factors controlling exchange. For $\mathrm{CO}_{2}$ a piston velocity of $0.65 \mathrm{~m} \mathrm{day}^{-1}$ was used (Richey et al. 2002), and for $\mathrm{CH}_{4}$ a piston velocity of $0.53 \mathrm{~m} \mathrm{day}^{-1}$ was used (Devol et al. 1990). These values were empirically estimated for Amazon lakes and floodplains that have conditions similar to the interfluvial wetlands in this study. The lack of meteorological measurements at the sites precludes calculation of piston velocities specific to the times of sampling.

The equilibrium gas concentration in water $\left(C_{\mathrm{eq}}\right)$ was calculated from atmospheric gas concentrations measured in each site (Eq. 2) using $K_{\mathrm{H}}=3.5 \times$ $10^{-2} \mathrm{M} \mathrm{atm}^{-1}$ for $\mathrm{CO}_{2}$ and $K_{\mathrm{H}}=1.4 \times 10^{-3} \mathrm{M}$ atm $^{-1}$ for $\mathrm{CH}_{4}$ (Sander 1999).

$K_{\mathrm{H}}=C_{\text {eq }} / P_{\mathrm{g}}$

$\mathrm{K}_{\mathrm{H}} \quad$ gas solubility coefficients

$\mathrm{C}_{\mathrm{eq}}$ gas concentration in liquid phase, $\mathrm{M}$

$\mathrm{P}_{\mathrm{g}} \quad$ gas partial pressure in gaseous phase, atm

\section{Statistical analysis}

The normality of all variables was tested with the $W$ test of Shapiro-Wilk. Additionally, to run ANOVA and $T$-test, the homogeneity of variances was tested with the Cochram $C$ test. When distributions were normal and variances were uniform, parametric tests were applied. Throughout \pm values indicate standard deviation. Two $\mathrm{CH}_{4}$ atmospheric values were excluded from the analysis as they were obviously outliers. To test the influence of site and habitat on diffusive emissions calculated by Fick's law a hierarchical nested ANOVA was run on the data collected at supplementary locations during July, August and November in the Cuini, Itu and Aracá wetlands. If differences among sites or habitats were significant, an Unequal N HSD post hoc test was run. A Mann-Whitney $U$ test was run to compare diffusive fluxes of floating and terrestrial chambers. A $T$ test was not used in this case because, even though the data were normally distributed, the variances were not homogeneous. The influence of the presence of emergent herbaceous macrophytes on methane emission was tested at each site with a $t$-test for dependent samples.

Differences between Cuini and Itu sites and the influence of habitats on the diffusive fluxes measured monthly at regular stations were tested by a hierarchical nested repeated measures ANOVA (RMA). Monthly differences of ebullitive fluxes between Cuini and Itu sites were also tested by RMA, but habitats were not tested because it was not feasible to use funnels at low water. If differences were significant, a Fisher post hoc test was run.

Influences of depth, concentration of dissolved oxygen and temperature of water on the emissions were examined by simple regression analyses. Data from the three wetlands were included together. To test the influence of variation in hydrostatic pressure on bubble release at Cuini and Itu sites, a $t$-test was run comparing ebullitive $\mathrm{CH}_{4}$ emissions when water was falling or rising.

Image analysis

Synthetic aperture radar data from Radarsat [C-band $(6 \mathrm{~cm}), \mathrm{HH}$ polarization] on 24 dates in 2004 and 2005 were used to determine inundated area in the Cuini and Itu wetlands. To reduce speckle, single look pixels were binned 4-1 resulting in $25 \mathrm{~m}$ resolution. A Landsat Thematic Mapper image obtained on 19 January 2003 was also used as part of the analysis, and additional Landsat TM images were used qualitatively. A wetland mask derived from an L-band SAR mosaic was used to mask uplands (Hess et al. 2003). The classification was based on temporal averages of Radarsat data using all dates with water depths between 60 and $80 \mathrm{~cm}, 80$ and $100 \mathrm{~cm}$, and 100 and $120 \mathrm{~cm}$ (as measured by the pressure transduces at the sites) in combination with Landsat TM band 5 (shortwave near infra-red), band 4 (near infra-red) and band 3 (red). Four general classes were identified: (1) unflooded forest or vegetated areas that did not permit detection of inundation; (2) regions with stronger radar backscatter as flooding increased indicative of flooding of emergent vegetation; (3) regions with consistently high backscatter indicative of permanently flooded vegetation; (4) regions with weaker radar backscatter as flooding increased, indicative of flooded emergent vegetation becoming submerged. A backscatter threshold (expressed as sigma ${ }_{0}$ ), indicative of flooding, was selected to discriminate flooded and unflooded regions on the date of each 
Radarsat acquisition. To evaluate the veracity of the designation of hydrological state, airborne videography collected during a period of high water was used (Hess et al. 2002).

Estimation of areal emission

Diffusive and ebullitive emissions of $\mathrm{CO}_{2}$ and $\mathrm{CH}_{4}$ were estimated for the Itu and Cuini wetlands. These were calculated by multiplying the daily measured emissions by the daily inundated area estimated for each site. The fluxes from unflooded areas were estimated with data collected by terrestrial chambers multiplied by the unflooded area of each site.

\section{Results}

Hydrometeorological data varied seasonally. Regional rainfall was higher in May and lower in October, and influenced the local water table (Fig. 3). Although water depth in wetlands varied seasonally with regional flooding, short-term variation in level responded to local rain. Therefore, variation of depth, when used in the statistical comparisons, was calculated as the difference in depth measured at midnight just after the collections were made and the depth measured at midnight one day before.

Superficial water temperature at the time of measurements of emissions averaged $28 \pm 2^{\circ} \mathrm{C}$ at Cuini and Itu sites ( $\mathrm{n}=30$ and $\mathrm{n}=48$, respectively). Bottom water temperatures recorded at midnight averaged $27 \pm 0.8^{\circ} \mathrm{C}$ at Cuini and Itu sites $(\mathrm{n}=894$

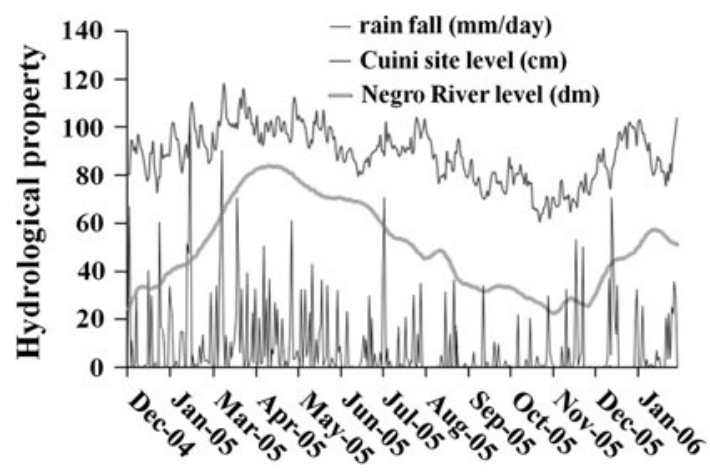

Fig. 3 Time series of daily hydrometeorological data. Daily rain fall $\left(\mathrm{mm} \mathrm{d}^{-1}\right)$ measured at Cuini site, variation in water level $(\mathrm{cm})$ at the Cuini wetland and variation in water level on the Negro River (dm) and $\mathrm{n}=717$, respectively). At Aracá, bottom temperature averaged $29 \pm 1.2^{\circ} \mathrm{C}(\mathrm{n}=840)$, and was higher at this site because the sensor was located in an open water area while at the other sites it was located under vegetation. Dissolved oxygen concentration varied from $3.5 \pm 1.6 \mathrm{mg} \mathrm{l}^{-1}$ near the surface to $2.6 \pm 1.5 \mathrm{mg} \mathrm{l}^{-1}$ near the bottom among the sites.

The average $\mathrm{CO}_{2}$ concentration in water was $391 \pm 213 \mu \mathrm{M}$ at the Cuini sites, $231 \pm 76 \mu \mathrm{M}$ at the Itu sites and $301 \pm 261 \mu \mathrm{M}$ at the Aracá site. $\mathrm{CO}_{2}$ was always supersaturated; the average equilibrium concentration was $28 \pm 7 \mu \mathrm{M}$. Hence, $\mathrm{CO}_{2}$ exchanges were from the water to the atmosphere. $\mathrm{CO}_{2}$ fluxes measured by floating chambers included negative and null fluxes and were erratic because 5 min increments in $\mathrm{CO}_{2}$ concentrations were frequently below the detection limit of chromatographic system used. Hence, we calculated diffusive fluxes by Fick's law. Ebullition of $\mathrm{CO}_{2}$ collected in funnels accounted only for less than $1 \%$ of the total $\mathrm{CO}_{2}$ emission (Table 2).

The average $\mathrm{CH}_{4}$ concentrations in water were $4.1 \pm 8.5 \mu \mathrm{M}$ at the Cuini sites, $1.9 \pm 2.4 \mu \mathrm{M}$ at the Itu sites and $2.9 \pm 5.1 \mu \mathrm{M}$ at the Aracá site. $\mathrm{CH}_{4}$ was supersaturated in superficial water; equilibrium concentrations were $0.0021 \pm 0.0008 \mu \mathrm{M}$. Hence, diffusive emissions calculated by Fick's law and measured by floating chambers were from the water to the atmosphere (Table 3), while terrestrial chambers had negative fluxes (mean $=3.6 \pm 4.8 \mathrm{mg} \mathrm{C} \mathrm{m}^{-2}$ $\mathrm{day}^{-1}$ ). Diffusive fluxes measured by floating and terrestrial chambers were statistically different ( $U$ yest; $p=0.0005$ ). The average $\mathrm{CH}_{4}$ emission measured with floating chambers $(19.3 \pm 39.9 \mathrm{mg} \mathrm{C}$ $\mathrm{m}^{-2}$ day $\left.^{-1}\right)$ and calculated by Fick's law (18 \pm $36 \mathrm{mg} \mathrm{C} \mathrm{m}^{-2}$ day $^{-1}$ ) were not statistically different ( $t$-test for dependent samples: $\mathrm{DF}=155 ; \quad p=$ $0.6914)$, and the fluxes were correlated $(n=122$, $\mathrm{r}=0.40, p<0.05$ ). Ebullition measured with floating chambers $\left(0.8 \pm 4.6 \mathrm{mg} \mathrm{C} \mathrm{m}^{-2}\right.$ day $\left.^{-1}\right)$ was lower than the measured by funnels $(29 \pm 69 \mathrm{mg} \mathrm{C}$ $\mathrm{m}^{-2}$ day $^{-1}$ ) demonstrating the reduced likelihood of capturing bubbles during short incubations. At the Cuini sites, $78 \%$ of $\mathrm{CH}_{4}$ was emitted by ebullition, while at the Itu sites only $24 \%$ of $\mathrm{CH}_{4}$ was emitted by ebullition (Table 3). $\mathrm{CH}_{4}$ emissions in the chambers covering an emergent macrophyte were higher at the Itu site ( $t$-test for dependent samples: $\mathrm{F}=$ 27, $p=0.0137$ ) with an average difference of 
Table 2 Mean, minimum and maximum values and standard deviations of ebullitive $\mathrm{CO}_{2}$ emission measured by funnels and diffusive $\mathrm{CO}_{2}$ emission calculated by Fick's law at $\mathrm{N}$ locations in Cuini, Itu and Aracá wetlands

\begin{tabular}{|c|c|c|c|c|c|c|c|}
\hline \multirow[t]{2}{*}{ Site } & \multirow[t]{2}{*}{ Emission form } & \multirow[t]{2}{*}{ Measurement method } & \multirow[t]{2}{*}{$\mathrm{N}$} & \multicolumn{4}{|c|}{$\mathrm{CO}_{2}$ emission $\left(\mathrm{mg} \mathrm{C} \mathrm{m}^{-2}\right.$ day $\left.^{-1}\right)$} \\
\hline & & & & Mean & Minimum & Maximum & SD \\
\hline \multirow[t]{2}{*}{ Cuini } & Ebullition & Funnel & 41 & 5 & 0 & 17 & 4 \\
\hline & Diffusion & Fick & 147 & 2801 & 85 & 7310 & 1649 \\
\hline \multirow[t]{2}{*}{ Itu } & Ebullition & Funnel & 82 & 2 & 0 & 8 & 2 \\
\hline & Diffusion & Fick & 211 & 1611 & 279 & 3596 & 574 \\
\hline Aracá & Diffusion & Fick & 62 & 2155 & 170 & 7810 & 2037 \\
\hline
\end{tabular}

$7.2 \pm 14.6 \mathrm{mg} \mathrm{CH}_{4} \mathrm{~m}^{-2}$ day $^{-1}$; this was not observed at the Cuini site ( $t$-test for dependent samples: $\mathrm{DF}=9, p=0.2261$ ).

Water depth did not affect $\mathrm{CO}_{2}$ and $\mathrm{CH}_{4}$ diffusive or ebullitive emissions $(p>0.05)$, but there was higher ebullitive $\mathrm{CH}_{4}$ emission when the water level was falling ( $t$-test: $\mathrm{DF}=121, p=0.0003)$. Bubbling at the Cuini sites when water level was falling and rising was $105 \pm 140$ and $55 \pm 62 \mathrm{mg} \mathrm{CH}_{4} \mathrm{~m}^{-2}$ day $^{-1}$, respectively. At the Itu site, these rates were $16 \pm 42$ and $3 \pm 6 \mathrm{mg} \mathrm{CH}_{4} \mathrm{~m}^{-2}$ day $^{-1}$, respectively. Dissolved oxygen in bottom waters was negatively correlated with $\mathrm{CO}_{2}\left(\mathrm{R}^{2}=-0.36, p<0.0001\right)$ and $\mathrm{CH}_{4}$ fluxes $\left(\mathrm{R}^{2}=-0.14, p<0.0001\right)$.

$\mathrm{CO}_{2}$ diffusive emissions were higher at the Cuini sites and higher at locations with shrubs and trees (post hoc test; Fig. 4). An ANOVA, based on supplementary locations, indicated differences in
$\mathrm{CO}_{2}$ diffusive emissions among sites ( $\mathrm{DF}=2 ; p=$ $0.0007)$ and habitats (DF $=8 ; p<0.0001) . \mathrm{CH}_{4}$ diffusive emissions were higher in grass habitats at Cuini, in palm habitats in the Itu wetland and in forest habitats in the Aracá wetland (post hoc tests; Fig. 4). Habitat differences were significant (ANOVA: DF = $8 ; p<0.0001)$.

Monthly variations in $\mathrm{CO}_{2}$ diffusive emissions were significant (RMA; DF $=11 ; p=0.0001)$, and these variations differed between the Cuini and Itu sites (RMA: DF $=11 ; p=0.0087$; Fig. 5).

$\mathrm{CH}_{4}$ emissions calculated by Fick's law differed among months $(\mathrm{DF}=11, p=0.0077)$, among sites $(\mathrm{DF}=11, p=0.0027)$ and habitats $(\mathrm{DF}=55, p=$ 0.0015) based on RMA as a result of $\mathrm{CH}_{4}$ emissions in the grass habitat of the Cuini site from July to September (Fisher post hoc test; Fig. 6). Ebullitive $\mathrm{CH}_{4}$ emission were higher at the Cuini sites than at

Table 3 Mean, minimum, and maximum values and standard deviations of $\mathrm{CH}_{4}$ emission measured in $\mathrm{N}$ locations in $\mathrm{Cuini}$, Itu, and Aracá wetlands

\begin{tabular}{|c|c|c|c|c|c|c|c|}
\hline \multirow[t]{2}{*}{ Site } & \multirow[t]{2}{*}{ Emission form } & \multirow[t]{2}{*}{ Measurement method } & \multirow[t]{2}{*}{$\mathrm{N}$} & \multicolumn{4}{|c|}{$\mathrm{CH}_{4}$ emissions (mg C m${ }^{-2}$ day $^{-1}$ ) } \\
\hline & & & & Mean & Min & Max & SD \\
\hline \multirow[t]{5}{*}{ Cuini } & \multirow[t]{2}{*}{ Ebullition } & Funnel & 41 & 75.2 & 0.1 & 392.8 & 101.4 \\
\hline & & $\mathrm{CF}$ & 65 & 1.7 & 0.0 & 53.8 & 7.1 \\
\hline & \multirow[t]{3}{*}{ Diffusion } & $\mathrm{CF}$ & 63 & 21.5 & 0.0 & 284.6 & 50.0 \\
\hline & & $\mathrm{CT}$ & 2 & -7.2 & -10.7 & -3.8 & 4.8 \\
\hline & & Fick & 147 & 25.8 & 0.2 & 474.6 & 54.0 \\
\hline \multirow[t]{5}{*}{ Itu } & \multirow[t]{2}{*}{ Ebullition } & Funnel & 82 & 5.9 & 0.0 & 161.0 & 19.9 \\
\hline & & $\mathrm{CF}$ & 100 & 0.2 & 0.0 & 8.8 & 1.0 \\
\hline & \multirow[t]{3}{*}{ Diffusion } & $\mathrm{CF}$ & 94 & 17.9 & 0.0 & 275.9 & 31.6 \\
\hline & & CT & 6 & -2.5 & -8.8 & 2.1 & 4.7 \\
\hline & & Fick & 211 & 12.2 & 0.8 & 131.0 & 15.2 \\
\hline Aracá & Diffusion & Fick & 62 & 18.7 & 0.0 & 163.5 & 32.5 \\
\hline
\end{tabular}

Ebullitive emissions were measured with inverted funnels (funnel) and floating chambers $(C F)$ and diffusive emissions were measured with floating chambers $(C F)$ and terrestrial chambers $(C T)$ and calculated by Fick's law (Fick) 
the Itu sites $(\mathrm{DF}=1, p<0.0317)$, and emissions varied significantly over time $(\mathrm{DF}=11, p<0.0001)$ and among sites (DF $=11, p<0.0001$; Fig. 7). Fisher post hoc test detected no difference in bubbling among months at the Itu sites, in contrast to the Cuini sites where bubbling was significantly lower in February and March, increasing gradually to a peak in October before declining.

Total area of the Cuini site calculated by the image analysis was $1685 \mathrm{~km}^{2}$, and the average of flooded area was $872 \mathrm{~km}^{2} \quad$ (minimum $=784$; maximum $=964), 52 \%$ of the total area (Fig. 2). Melack et al. (2009) present a duration of inundation map for this region. Since flooded area was directly related to the gauge water level $\left(\mathrm{R}^{2}=0.82 ; p<0.0001\right)$, an inundation model for the Cuini wetland was made using data from the Cuini water level gauge (Eq. 3):

$\mathrm{A}=551.15+3.74 \mathrm{GL}$
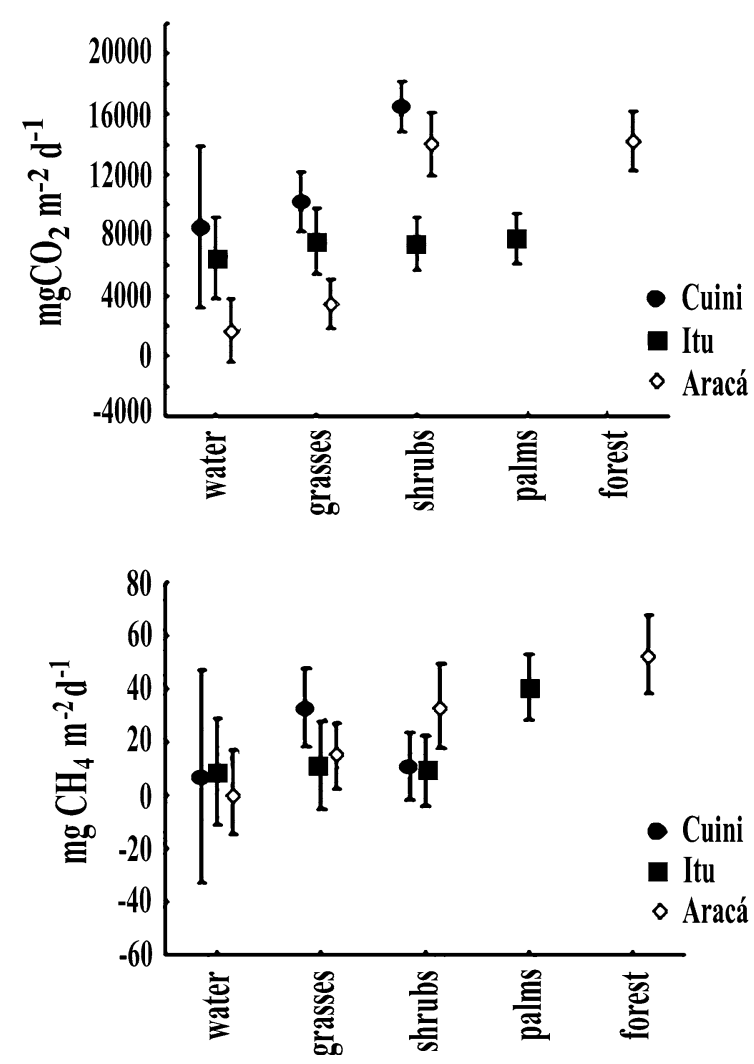

Fig. 4 Variation (mean and standard deviation) of $\mathrm{CO}_{2}$ and $\mathrm{CH}_{4}$ diffusive emissions calculated by Fick's law from the habitats at Cuini, Itu, and Aracá sites

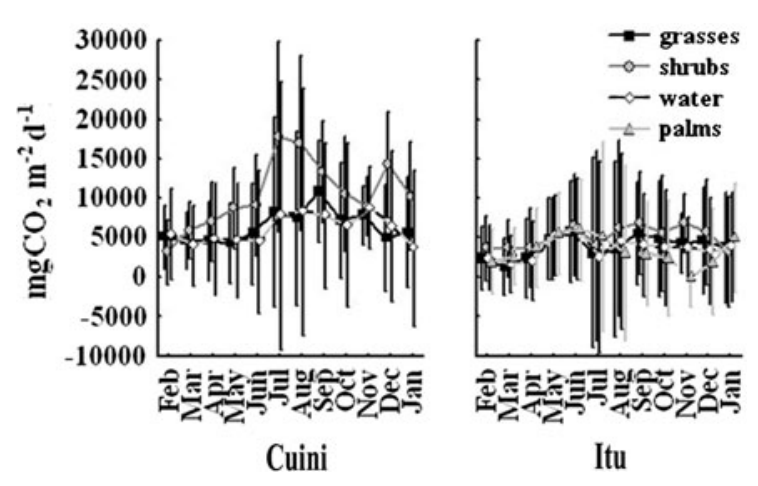

Fig. 5 Monthly variation (mean and standard deviation) of $\mathrm{CO}_{2}$ diffusive emissions calculated by Fick's law in the habitats at Cuini and Itu sites

\section{A Flooded area $\left(\mathrm{km}^{2}\right)$ \\ GL gauge level (cm)}

The total area of Itu site was $1295 \mathrm{~km}^{2}$, and the average of flooded area was $684 \mathrm{~km}^{2}$ (minimum = 550 ; maximum $=762$ ), $53 \%$ of the total area. The flooded area related to the site specific Itu water level gauge $\left(\mathrm{R}^{2}=0.59 ; p=0.0003\right)$, was less strong than the relation with the Negro River level $\left(R^{2}=0.86\right.$; $p<0.0001$ ), which controls the regional level in the Itu River; hence an inundation model was made for Itu site using Negro River level (Eq. 4):

$\mathrm{A}=551.26+2.73 \mathrm{RL}$

\section{A Flooded area $\left(\mathrm{km}^{2}\right)$ \\ RL Negro River level (cm)}

Average daily diffusive and ebullitive emissions were multiplied for the total flooded area at each site. The estimation of diffusive $\mathrm{CO}_{2}$ emission was made
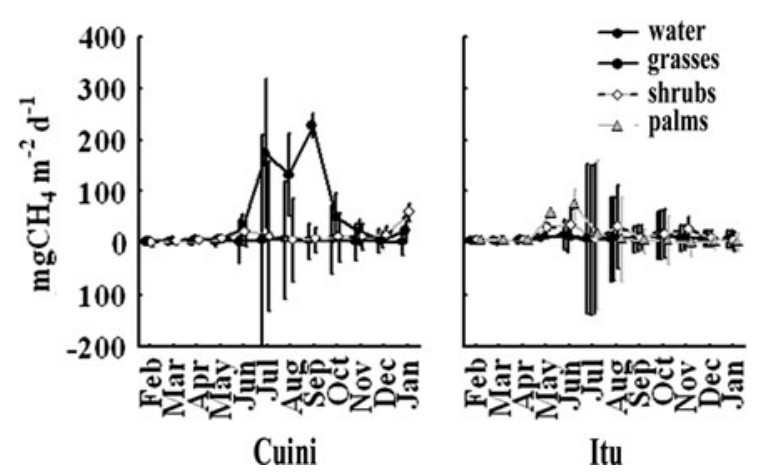

Fig. 6 Monthly variation of $\mathrm{CH}_{4}$ diffusive emissions calculated by Fick's law (mean and standard deviation) in the habitats at Cuini and Itu sites 


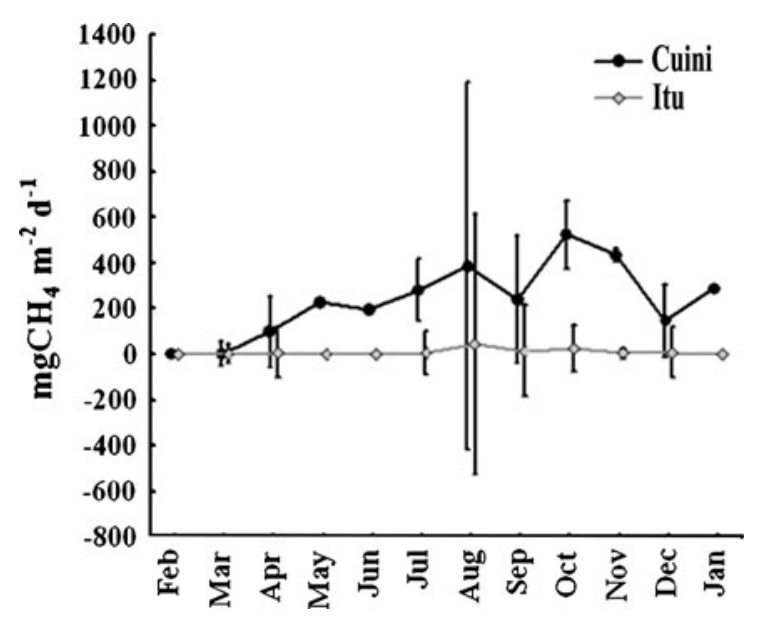

Fig. 7 Monthly variation of $\mathrm{CH}_{4}$ ebullitive emissions measured by funnels (mean and standard deviation) at Cuini and Itu sites

from the data calculated by Fick's law. The estimate of $\mathrm{CH}_{4}$ diffusive emission was made from the measures made with floating chambers. Depth did not affect diffusive or ebullitive emissions of $\mathrm{CO}_{2}$ and $\mathrm{CH}_{4}$, but there was a seasonal variation in emissions. Hence, daily $\mathrm{CO}_{2}$ ebullitive emission and the daily $\mathrm{CO}_{2}$ and $\mathrm{CH}_{4}$ diffusive emissions of flooded areas in the intervals between two collections was estimated as being the average of the emissions measured in the beginning and end of each interval. The daily emissions were multiplied by total flooded area for each day estimated by Eq. 2 for the Cuini wetland and by Eq. 3 for the Itu wetland. As $\mathrm{CH}_{4}$ ebullitive emission differed mainly between periods of rising and falling water level, ebullitive emission was determined by only this factor. When the level at the Cuini site was lower than the level of the previous day, the average daily emission was $105 \mathrm{mg}$ $\mathrm{CH}_{4} \mathrm{~m}^{-2}$ day $^{-1}$. When the level was rising, the average daily emission was $55 \mathrm{mg} \mathrm{CH}_{4} \mathrm{~m}^{-2}$ day $^{-1}$. When water level at the Itu site was falling, the average daily emission was $16 \mathrm{mg} \mathrm{CH}_{4} \mathrm{~m}^{-2}$ day $^{-1}$. When the level was rising, the average daily emission was $3 \mathrm{mg} \quad \mathrm{CH}_{4} \quad \mathrm{~m}^{-2}$ day $^{-1}$. The diffusive $\mathrm{CO}_{2}$ emission when environment was unflooded was considered zero, since the terrestrial chambers registered no or very low emissions at this time. $\mathrm{CH}_{4}$ flux was calculated as an average of the rates measured in the terrestrial chambers of $-9.5 \mathrm{mg} \mathrm{CH}_{4} \mathrm{~m}^{2}$ day $^{-1}$ for Cuini sites and of $-3.3 \mathrm{mg} \mathrm{CH}_{4} \mathrm{~m}^{2}$ day $^{-1}$ for Itu sites. The daily average fluxes were multiplied by the
Table 4 Ebullitive and diffusive emission of $\mathrm{CO}_{2}$ and $\mathrm{CH}_{4}$ from flooded and unflooded areas in Cuini and Itu wetlands

\begin{tabular}{|c|c|c|c|c|c|}
\hline \multirow[t]{2}{*}{ Site } & \multirow[t]{2}{*}{ Gas } & \multirow{2}{*}{$\begin{array}{l}\text { Emission } \\
\text { form }\end{array}$} & \multicolumn{3}{|c|}{ Flux $\left(\mathrm{Gg} C\right.$ year $\left.^{-1}\right)$} \\
\hline & & & $\begin{array}{l}\text { Flooded } \\
\text { area }\end{array}$ & $\begin{array}{l}\text { Unflooded } \\
\text { area }\end{array}$ & Total \\
\hline \multirow[t]{4}{*}{ Cuini } & \multirow[t]{2}{*}{$\mathrm{CO}_{2}$} & Ebullition & 1.9 & 0 & 1.9 \\
\hline & & Diffusion & 790 & 0 & 790 \\
\hline & \multirow[t]{2}{*}{$\mathrm{CH}_{4}$} & Ebullition & 20 & 0 & 20 \\
\hline & & Diffusion & 7.6 & -2.1 & 5.5 \\
\hline \multirow[t]{4}{*}{ Itu } & \multirow[t]{2}{*}{$\mathrm{CO}_{2}$} & Ebullition & 0.5 & 0 & 5 \\
\hline & & Diffusion & 350 & 0 & 350 \\
\hline & \multirow[t]{2}{*}{$\mathrm{CH}_{4}$} & Ebullition & 1.6 & 0 & 1.6 \\
\hline & & Diffusion & 4.3 & -0.6 & 3.7 \\
\hline
\end{tabular}

unflooded area of each site for the corresponding day. The daily emissions of the flooded and unflooded areas of each site were added and integrated for the period from February, 2005 to January, 2006 to obtain the monthly and the total annual $\mathrm{CO}_{2}$ and $\mathrm{CH}_{4}$ emissions (Table 4).

Higher $\mathrm{CO}_{2}$ and $\mathrm{CH}_{4}$ emissions occurred from June to July at the Itu site and for $\mathrm{CO}_{2}$ at the Cuini site (Fig. 8). Higher $\mathrm{CH}_{4}$ emission occurred in August and September and from November to January at the Cuini site. Summed over the year $\mathrm{CO}_{2}$ emissions were $792 \mathrm{Gg} \mathrm{C}_{\text {year }}{ }^{-1}$ for the Cuini wetland and $355 \mathrm{Gg} \mathrm{C}_{\text {year }}{ }^{-1}$ for Itu wetland. Similarly, $\mathrm{CH}_{4}$ emissions were $25.5 \mathrm{Gg} \mathrm{C}_{\text {year }}{ }^{-1}$ for the Cuini wetland and $5.3 \mathrm{Gg} \mathrm{C}_{\text {year }}{ }^{-1}$ for Itu wetland. Total emissions in $\mathrm{CO}_{2}$ warming equivalence were $1328 \mathrm{Gg} \mathrm{C}_{\mathrm{eq}}$ year $^{-1}$ for the Cuini wetland and $466 \mathrm{Gg} \mathrm{C}_{\mathrm{eq}}$ year $^{-1}$ for the Itu wetland.

\section{Discussion}

$\mathrm{CO}_{2}$ and $\mathrm{CH}_{4}$ were always found to be supersaturated in surficial waters of upper Negro wetlands, while dissolved oxygen, even in surficial waters, was always found to be below saturation. $\mathrm{CO}_{2}$ and $\mathrm{CH}_{4}$ emissions were found to be higher when dissolved oxygen was lower in waters near the bottom. The same pattern was observed in central Amazon floodplains (Bartlett et al. 1990; Devol et al. 1988, 1994). Emissions of $\mathrm{CO}_{2}$ and $\mathrm{CH}_{4}$ were negatively correlated to dissolved oxygen concentrations near the bottom of the water column. These observations 
Fig. 8 Monthly fluxes of $\mathrm{CO}_{2}$ (top) and $\mathrm{CH}_{4}$ (bottom) of the Cuini (left) and Itu sites (right) by ebullition and diffusion from flooded soil and by diffusion from unflooded soil (gray bars)

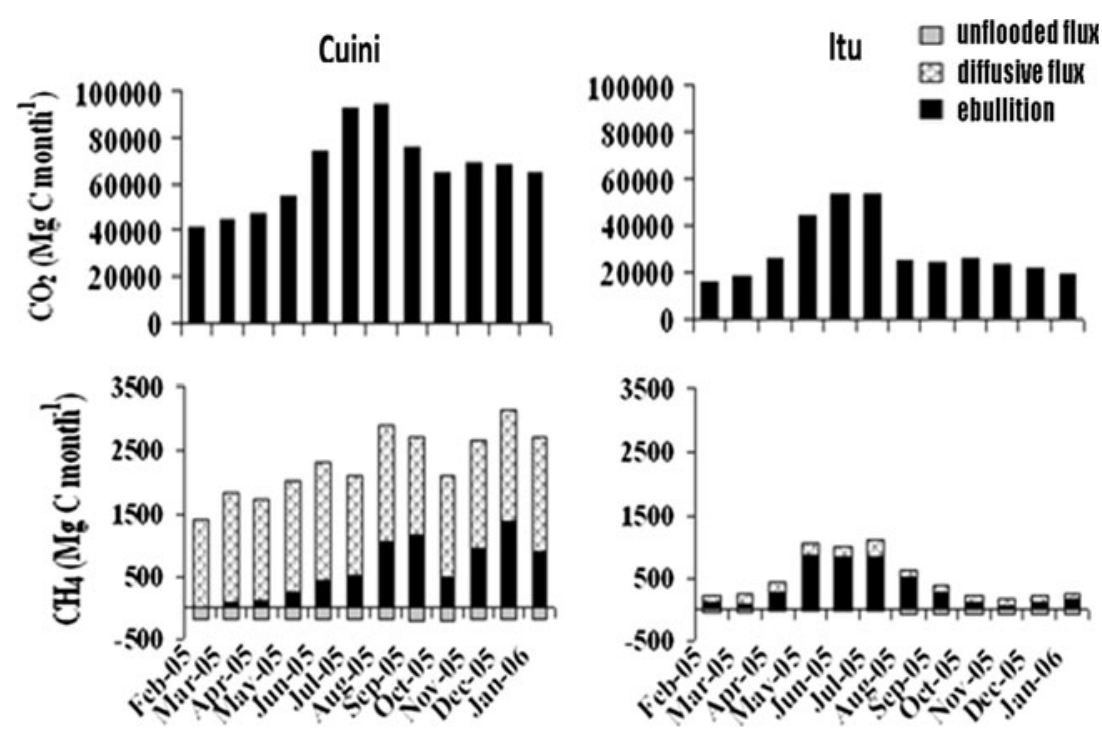

are a result of $\mathrm{CO}_{2}$ production during aerobic respiration and concomitant consumption of $\mathrm{O}_{2}$ (Ballester and Santos 2001; Hamilton et al. 1995), and methanogenesis occurring mainly under anoxic conditions (Mer and Roger 2001).

Average $\mathrm{CH}_{4}$ surficial concentrations at the Cuini, Itu and Aracá sites $(4.1,1.9$, and $2.9 \mu \mathrm{M}$, respectively) were similar to average values of $2.9 \mu \mathrm{M}$ (Engle and Melack 2000) and of $4.0 \mu \mathrm{M}$ (Crill et al. 1988) measured in central Amazon floodplain lakes when they were shallow and without thermal stratification. When the lakes in the Amazon and Pantanal were deeper than $3 \mathrm{~m}$ with a persistent thermocline, they had lower average values in surface of $0.25 \mu \mathrm{M}$ (Engle and Melack, 2000) and 0.1-0.9 $\mu \mathrm{M}$ (Hamilton et al. 1995; 1997) and methane accumulated in deeper water (Crill et al. 1988; Engle and Melack 2000). Total emission measured near shore was often higher than in deeper environments (Rosenqvist et al. 2002).

Average methane diffusive emissions from the Cuini and Itu sites calculated by Fick's law (25.8 and $12.2 \mathrm{mg} \mathrm{C} \mathrm{m}^{-2}$ day $^{-1}$, respectively) were higher than the average of $4.9 \mathrm{mg} \mathrm{C} \mathrm{m}^{-2}$ day $^{-1}$ calculated by Fick's law by Engle and Melack (2000) in a central Amazon floodplain lake. These lakes can be up to $12 \mathrm{~m}$ deep, while the Cuini and Itu sites were not deeper than $2 \mathrm{~m}$. This difference may also reflect differences in the method of calculation: Engle and Melack (2000) considered data from chambers as total emission, diffusive emission was calculated with Fick's law and bubbling was the difference. In contrast, we considered chambers to measure only diffusive flux, and bubbling were measured with inverted funnels.

$\mathrm{CH}_{4}$ ebullitive emission measured in floating chambers was only $7 \%$ of that measured by inverted funnels; the 15 min deployment period of chambers was apparently too short to capture many bubbles. Previous studies in Amazon wetlands calculated bubbling using chambers and probably underestimated ebullition (Devol et al. 1990; Engle and Melack 2000; Rosenqvist et al. 2002).

Total methane flux from upper Negro wetlands (average $60 \mathrm{mg} \mathrm{C} \mathrm{m}^{-2} \mathrm{day}^{-1}$ ) was similar to total fluxes from a shallow lake in the Pantanal (Alvalá et al. 1999) and was lower than total emissions from central Amazon floodplains (Melack et al. 2004). $\mathrm{CH}_{4}$ diffusive emissions measured by floating chambers and calculated by Fick's law using an average piston velocity suggested by Devol et al. (1990) for central Amazon floodplains were similar, but the fluxes were not strongly correlated, probably because actual piston velocities varied as a function of wind speed and convective mixing.

The proportion of ebullitive $\mathrm{CH}_{4}$ emissions at the Cuini sites was close to values observed for other Amazon and Orinoco sites (Devol et al. 1988; Engle and Melack 2000; Rosenqvist et al. 2002; Smith et al. 2000), while the Itu sites had little ebullition. This may occur because sediments at Itu sites were sandy and compact while Cuini sites had soft muddy soil where more methane could be produced and stored. 
$\mathrm{CO}_{2}$ and $\mathrm{CH}_{4}$ concentrations and emissions were higher at the Cuini sites than the other sites. Most of the area was permanently flooded, and $\mathrm{CH}_{4}$ emission averaged $97 \mathrm{mg} \mathrm{C} \mathrm{m}^{-2} \mathrm{day}^{-1}$, similar to values of $106 \mathrm{mg} \mathrm{C} \mathrm{m}^{-2}$ day $^{-1}$ observed for permanently flooded, shallow lakes in the Pantanal (Marani and Alvalá 2007). In contrast, the Itu sites were seasonally flooded and had average $\mathrm{CH}_{4}$ emission of $24 \mathrm{mg} \mathrm{C} \mathrm{m}^{-2}$ day $^{-1}$. A similar difference was observed in wetlands of North America where seasonally flooded environments emitted about $30 \%$ of the $\mathrm{CH}_{4}$ of permanently flooded sites (Altor and Mitsch 2006). The organic-rich sediments at the Cuini sites in comparison to the sandy sediments at the Itu and Aracá sites are likely to also have contributed to the differences among the sites.

The higher emission rates measured by floating chambers placed over flooded vegetation at Itu sites suggest that emergent macrophytes at this site are transporting methane from the sediments to the atmosphere through their aerenchyma, as has been observed elsewhere (Kim et al. 1999; King et al. 1998) and demonstrated in laboratory experiments (Garnet et al. 2005). The apparent absence of this process at the Cuini sites may be related to differences in sediments and vegetation between the sites. The Cuini sites were shallow, but permanently flooded, resulting in anoxic sediments. In response, the herbaceous macrophytes formed dense adventitious roots above the sediment surface which improved oxygen availability but reduced the potential for aerenchymal methane flow from the sediments to the atmosphere. The sediments at the Itu sites were seasonally dry and thus better oxygenated. The roots of emergent macrophytes were well developed in these sediments and apparently resulted in efficient transport of methane from the sediments through aerenchymal tissue to the atmosphere.

Diffusive $\mathrm{CH}_{4}$ fluxes measured in chambers deployed in interfluvial wetlands of the upper Negro basin revealed that consumption of $\mathrm{CH}_{4}$ occurred in unflooded environments and emission occurred from flooded environments. This pattern has been observed in wetlands throughout the world (Castaldi et al. 2006; Liblik et al. 1997) including the Amazon, where methane was oxidized and production decreased during the period soil was exposed to the atmosphere (Koschorreck 2000). An important implication of the consumption of methane in unflooded soils is the conversion of a region from one where methane is consumed to one where it is produced when reservoirs are constructed (Kemenes et al. 2007). As hydroelectric dams are planned for the Amazon and other tropical locations, the resulting changes in the methane fluxes should be considered as one component of the environmental consequences of the creation of reservoirs.

Organic carbon inputs to the interfluvial wetlands are provided largely by periphyton growing on submerged surfaces, from emergent sedges and grasses and from palms and shrubs with a small contribution from atmospheric deposition. In contrast to floodplains elsewhere in the Amazon basin which can receive significant inputs from rivers and local runoff (Melack and Engle 2009), most of the interfluvial wetlands drain to rivers via small streams. No data on the productivity of the alga or plants or on other carbon inputs are available from these or similar sites. Hence, analogously to papers such as Richey et al. (2002), it is our purpose to show the flux of carbon dioxide from the open water of these wetlands, not calculate the net ecosystem exchange, which would require an eddy flux tower and measurements of carbon inputs from each source, such as reported for Lake Calado (Melack and Engle 2009) or for a reach along the Solimões River (Melack and Forsberg 2001).

Interfluvial wetlands in the upper Negro basin emitted, summing diffusion, ebullition and transport though aerenchyma, an average of $2193 \mathrm{mg} \mathrm{C}$ $\mathrm{m}^{-2}$ day $^{-1}$ as $\mathrm{CO}_{2}$ and $60 \mathrm{mg} \mathrm{C} \mathrm{m}{ }^{-2}$ day $^{-1}$ as $\mathrm{CH}_{4}$ when flooded and consumed $4.8 \mathrm{mg} \mathrm{C} \mathrm{m}^{-2}$ day $^{-1}$ as $\mathrm{CH}_{4}$ when unflooded. Based on the estimates of annual emission for both the Cuini and Itu wetlands, the interfluvial wetlands emit approximately $770 \mathrm{Mg}$ $\mathrm{C} \mathrm{km}^{-2}$ year $^{-1}$ as $\mathrm{CO}_{2}$ and $21 \mathrm{Mg} \mathrm{C} \mathrm{km}^{-2}$ year $^{-1}$ as $\mathrm{CH}_{4}$. By comparison, Richey et al. (2002) reported $\mathrm{CO}_{2}$ outgassing of $830 \pm 240 \mathrm{Mg} \mathrm{C} \mathrm{km}^{-2}$ year $^{-1}$ as $\mathrm{CO}_{2}$ for central Amazon floodplains, Rosenqvist et al. (2002) reported methane emission of $23 \mathrm{Mg} \mathrm{C}$ $\mathrm{km}^{-2}$ year $^{-1}$ for flooded forests in the blackwater Jau basin, and Melack et al. (2004) calculated $30 \mathrm{Mg} \mathrm{C} \mathrm{km}^{-2}$ year ${ }^{-1}$ as $\mathrm{CH}_{4}$ for the central Amazon floodplains.

In the lowland Amazon basin of Brazil there are approximately $152,000 \mathrm{~km}^{2}$ of hydromorphic soils (Radambrasil 1972) generally covered by flooded areas similar to those included in our study. By 
extrapolating our estimates of emission to this whole area and assuming that the region is flooded about half the year, we calculate that interfluvial Amazon wetlands emit $63 \mathrm{Tg} \mathrm{C}$ year ${ }^{-1}$ as $\mathrm{CO}_{2}$ and $1.7 \mathrm{Tg} \mathrm{C}$ year ${ }^{-1}$ as $\mathrm{CH}_{4}$ and absorb $0.13 \mathrm{Tg} \mathrm{C}$ year ${ }^{-1}$ as $\mathrm{CH}_{4}$. Alternatively, Junk (1997) estimated that the wetlands in the middle Negro basin cover approximately $50,000 \mathrm{~km}^{2}$, a value close to that reported by Frappart et al. (2005) for the region in the vicinity of our studies. Using this area and assuming the region is flooded about half the year results in an estimate of $21 \mathrm{Tg} \mathrm{C}_{\text {year }}{ }^{-1}$ as $\mathrm{CO}_{2}$ and $0.6 \mathrm{Tg} \mathrm{C}$ year ${ }^{-1}$ as $\mathrm{CH}_{4}$ emitted. Either of these values are significant in relation to estimated emissions of carbon dioxide and methane from wetlands in a 1.77 million $\mathrm{km}^{2}$ region in the central Amazon basin of $210 \pm 60 \mathrm{Tg}$ C year ${ }^{-1}$ (Richey et al. 2002) and $6.8 \pm 1.6 \mathrm{Tg} \mathrm{C}$ year $^{-1}$ (Melack et al. 2004).

Acknowledgments We thank NASA's LBA-ECO program for the financial support, FAPEAM for scholarship, the Rio Negro Lodge Foundation for field support, and M. Gastil-Buhl for assistance with analysis of the SAR and Landsat data.

Open Access This article is distributed under the terms of the Creative Commons Attribution Noncommercial License which permits any noncommercial use, distribution, and reproduction in any medium, provided the original author(s) and source are credited.

\section{References}

Altor AE, Mitsch WJ (2006) Methane flux from created riparian marshes: relationship to intermittent versus continuous inundation and emergent macrophytes. Ecol Eng 28:224-234

Alvalá PC, Kirchhoff VWJH, Pavão HG (1999) Metano na atmosfera: produção de metano em regiões de queimadas e áreas alagadas. Biotecnol Cienc Desenvolv 2:40-43

Ballester MVR, Santos JE (2001) Biogenic gases in tropical floodplain river. Braz Arch Biol Technol 44:141-147

Bartlett KB, Crill PM, Bonassi JA, Richey JE, Harriss RC (1990) Methane flux from the Amazon River floodplain: emissions during rising water. J Geophys Res 95: 16773-16788

Broecker WS, Peng TH (1982) Traces in the sea. Eldigio Press, New York

Castaldi S, Ermice A, Strumia S (2006) Fluxes of $\mathrm{N}_{2} \mathrm{O}$ and $\mathrm{CH}_{4}$ from soils of savannas and seasonally-dry ecosystems. J Biogeogr 33:401-415

Crill PM, Bartlett KB, Wilson JO, Sebacher DI, Harriss RC, Melack JM, MacIntyre S, Lesack L, Smith-Morrill L (1988) Tropospheric methane from an Amazonian floodplain lake. J Geophys Res 93:1564-1570
Dacey JWH, Klug MJ (1979) Methane efflux from lake sediments through water lilies. Science 203:1253-1254

Devol AH, Richey JE, Clark WA, King SL, Martinelli LA (1988) Methane emissions to the troposphere from the Amazon floodplain. J Geophys Res 93:1583-1592

Devol AH, Richey JE, Forsberg BR, Martinelli LA (1990) Seasonal dynamics in methane emissions from the Amazon River floodplain to the troposphere. J Geophys Res 95:16417-16426

Devol AH, Richey JE, Forsberg BR, Martinelli LA (1994) Envirinmental methane in the Amazon River floodplain. In: Mitsch WJ (ed) Global wetlands: Old world and new. Elsevier Science, Amsterdam, pp 151-165

Engle D, Melack JM (2000) Methane emissions from an Amazon floodplain lake: enhanced release during episodic mixing and during falling water. Biogeochemistry 51: $71-90$

Ferreira E, Zuanon J, Forsberg BR, Goulding M, Ferreira SB (2007) Rio Branco: Peixes, Ecologia e conservação de Roraima. Lima Peru: INPA/ACCA. p 201

Frappart F, Seyler F, Martinez J-M, León JG, Cazenave A (2005) Flooplain water storage in the Negro River basin estimated from microwave remote sensing of inundated area and water levels. Remote Sens Environ 99:387-399

Garnet KN, Megonigal P, Litchfield C (2005) Physiological control of leaf methane emission from wetland plants. Aquat Bot 81:141-155

Hamilton SK, Sippel SJ, Melack JM (1995) Oxygen depletion and carbon-dioxide and methane production in waters of the Pantanal wetland of Brazil. Biogeochemistry 30:115-141

Hamilton SK, Sippel SJ, Calheiros DF, Melack JM (1997) An anoxic event and other biogeochemical effects of the Pantanal wetland on the Paraguay River. Limnol Oceanogr 42:257-272

Hamilton SK, Sippel SJ, Melack JM (2002) Comparison of inundation patterns among major South American floodplains. J Geophys Res 107(D20), doi:10.1029/2000JD000306

Hansch C, Leo AJ (1979) Substitute constants for correlation analysis in chemistry and biology. Wiley, New York

Hess LL, Novo EMLM, Slaymaker DM, Holt J, Steffen C, Valeriano DM, Mertes LAK, Krug T, Melack JM, Gastil M, Holmes C, Hayward C (2002) Geocoded digital videography for validation of land cover mapping in the Amazon basin. Int J Remote Sens 7:1527-1556

Hess LL, Melack JM, Novo EMLN, Barbosa CCF, Gastil M (2003) Dual-season mapping of wetland inundation and vegetation for the central Amazon basin. Remote Sens Environ 87:404-428

Hope D, Dawson JJC, Cresser MS, Billett MF (1995) A method for measuring free $\mathrm{CO}_{2}$ in upland streamwater using headspace analysis. J Hydrol 166:1-14

Junk WJ (1993) Wetlands of tropical South America. In: Whigham DF, Hejny S, Dykyjova D (eds) Wetlands of the World. Kluwer, Dordrecht, pp 679-739

Junk WJ (1997) The central amazon floodplain. Springer, Berlin

Kemenes A, Forsberg BR, Melack JM (2007) Methane release below a tropical hydroelectric dam. Geophys Res Lett 34:L12809. doi:10.1029/2007GL029479

Kim J, Verma SB, Billesbach DP (1999) Seasonal variation in methane emission from a temperate Phragmites-dominated 
marsh: effect of growth stage and plant-mediated transport. Global Change Biol 5:433-440

King JY, Reeburgh WS, Regli SK (1998) Methane emission and transport by arctic sedges in Alaska: results of a vegetation removal experiment. J Geophys Res 103:29083-29092

Koschorreck M (2000) Methane turnover in exposed sediments of an Amazon floodplain lake. Biogeochemistry 50: 195-206

Liblik LK, Moore TR, Bubier JL, Robinson SD (1997) Methane emissions from wetlands in the zone of discontinuous permafrost: fort Simpson, Northwest Territories, Canada. Global Biochem Cycles 11:485-494

MacIntyre S, Wanninkhof R, Chanton J (1995) Trace gas exchange across the air-water interface in freshwater and coastal marine environments. In: Matson P, Harriss R (eds) Biogenic trace gases: measuring emissions from soil and water. Blackwell, Cambridge, pp 52-97

Marani L, Alvalá PC (2007) Methane emissions from lakes and floodplains in Pantanal, Brazil. Atmos Environ 41: 1627-1633

Matson PA, Harriss RC (1995) Biogenic trace gases: measuring emissions from soil and water. Blackwell Science, Cambridge

Melack JM, Engle D (2009) An organic carbon budget for an Amazon floodplain lake. Verh Internat Verein Limnol 30:1179-1182

Melack JM, Forsberg BR (2001) Biogeochemistry of Amazon floodplain lakes and associated wetlands. In: McClain ME, Victoria RL, Richey JE (eds) The biogeochemistry of the Amazon Basin and its role in a changing world. Oxford University Press, New York, pp 235-276

Melack JM, Hess LL (2010) Remote sensing of the distribution and extent of wetlands in the Amazon basin. In Junk WJ, Piedade M (eds) Amazonian floodplain forests: ecophysiology, ecology, biodiversity and sustainable management. Ecological Studies, vol. 210, part 1. Springer, pp 43-59
Melack JM, Hess LL, Gastil M, Forsberg BR, Hamilton SK, Novo EMLN, Lima IBT (2004) Regionalization of methane emissions in the Amazon basin with microwave remote sensing. Global Change Biol 10:530-544

Melack JM, Novo EMLN, Forsberg BR, Piedade MTF, Maurice L (2009) Floodplain ecosystem processes. In: Gash J, Keller M, Silva-Dias P (eds) Amazonia and global change. Geophysical monograph series American geophysical union, Washington, pp 525-541

Mer JL, Roger P (2001) Production, oxidation, emission and consumption of methane by soils: a review. Eur J Soil Biol 37:25-50

Radambrasil (1972) Mosaicos semi-controlados de Radar 1: 250,000. Departamento Nacional da Produção Mineral, Rio de Janeiro, Brasil

Richey JE, Melack JM, Aufdenkampe AK, Ballester MVR, Hess LL (2002) Outgassing from Amazonian rivers and wetlands as a large tropical source of atmospheric $\mathrm{CO}_{2}$. Nature 416:617-620

Rosenqvist A, Forsberg BR, Pimentel T, Rauste YA, Richey JE (2002) The use of spaceborne radar data to model inundation patterns and trace gas emissions in the central Amazon floodplain. Int J Remote Sens 33:1303-1328

Sander, R (1999) Compilation of Henry'S Law constants for inorganic and organic species of potential importance in environmental chemistry. http://www.mpch-mainz.mpg. de/ sander/res/henry.html

Smith LK, Lewis WM, Chanton JP, Cronin G, Hamilton SK (2000) Methane emissions from the Orinoco River floodplain, Venezuela. Biogeochemistry 51:113-140

Whalen SC (2005) Biochemistry of methane exchange between natural wetlands and the atmosphere. Environ Eng Sci 22:73-93 